\title{
Article
}

\section{Assessing the effectiveness of micro- spring technology to reduce initial and peak loading rates when integrated into running footwear}

Sutcliffe, Melissa and Richards, Jim

Available at http://clok.uclan.ac.uk/12099/

Sutcliffe, Melissa and Richards, Jim ORCID: 0000-0002-4004-3115 (2015)

Assessing the effectiveness of micro-spring technology to reduce initial and peak loading rates when integrated into running footwear. Footwear Science, 7 (sup1). S72-S73.

It is advisable to refer to the publisher's version if you intend to cite from the work.

For more information about UCLan's research in this area go to

http://www.uclan.ac.uk/researchgroups/ and search for <name of research Group>.

For information about Research generally at UCLan please go to http://www.uclan.ac.uk/research/

All outputs in CLoK are protected by Intellectual Property Rights law, including Copyright law. Copyright, IPR and Moral Rights for the works on this site are retained by the individual authors and/or other copyright owners. Terms and conditions for use of this material are defined in the policies page. 
This article was downloaded by: [University of Central Lancashire]

On: 15 July 2015, At: 05: 51

Publisher: Taylor \& Francis

Informa Ltd Registered in England and Wales Registered Number: 1072954 Registered office: 5 Howick Place, London, SW1P IWG

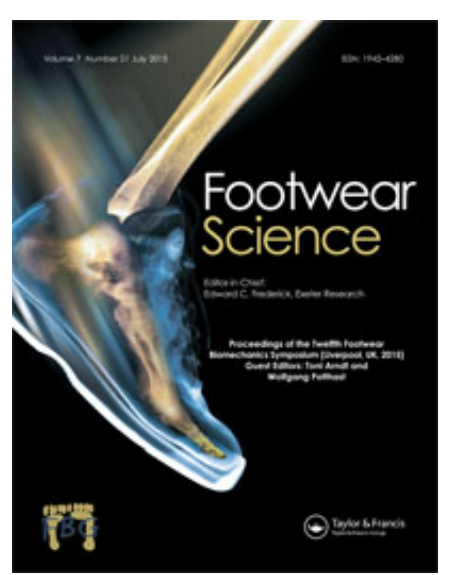

\section{Footwear Science}

Publication details, including instructions for authors and subscription information:

http:// www.tandfonline.com/loi/tfws20

\section{Assessing the effectiveness of micro-spring technology to reduce initial and peak loading rates when integrated into running footwear}

\author{
Melissa Sutcliffe ${ }^{a} \&$ J ames Richards ${ }^{a}$ \\ ${ }^{a}$ University of Central Lancashire, Preston, United Kingdom \\ Published online: 18 J un 2015.
}

\title{
(DrossMark \\ Click for updates
}

\begin{abstract}
To cite this article: Melissa Sutcliffe $\&$ J ames Richards (2015) Assessing the effectiveness of micro-spring technology to reduce initial and peak loading rates when integrated into running footwear, Footwear Science, 7:sup1, S72-S73, DOI: 10.1080/ 19424280.2015.1038614
\end{abstract}

To link to this article: http:// dx. doi.org/ 10.1080/ 19424280.2015.1038614

\section{PLEASE SCROLL DOWN FOR ARTICLE}

Taylor \& Francis makes every effort to ensure the accuracy of all the information (the "Content") contained in the publications on our platform. However, Taylor \& Francis, our agents, and our licensors make no representations or warranties whatsoever as to the accuracy, completeness, or suitability for any purpose of the Content. Any opinions and views expressed in this publication are the opinions and views of the authors, and are not the views of or endorsed by Taylor \& Francis. The accuracy of the Content should not be relied upon and should be independently verified with primary sources of information. Taylor and Francis shall not be liable for any losses, actions, claims, proceedings, demands, costs, expenses, damages, and other liabilities whatsoever or howsoever caused arising directly or indirectly in connection with, in relation to or arising out of the use of the Content.

This article may be used for research, teaching, and private study purposes. Any substantial or systematic reproduction, redistribution, reselling, loan, sub-licensing, systematic supply, or distribution in any form to anyone is expressly forbidden. Terms $\&$ Conditions of access and use can be found at http:// www.tandfonline.com/page/terms-and-conditions 
On the other hand, it has also been observed statistical differences depending on the gait gestures. For instance, running on a flat path remarkably increases the pressure on the rearfoot area and on the first and second metatarsal heads. Nevertheless, pressures on the tip of the sole decreases.

In case of $90^{\circ}$ and $180^{\circ}$ turns, the lateral side of the sole registers higher pressures than in walking condition. On the contrary, the tip of the sole seldom contacts the floor. Finally, $180^{\circ}$ turn reduces considerably the pressures under the toes in comparison to the $90^{\circ}$ turn.

\section{Discussion and conclusion}

The study shows that the proposed methodology is useful to determine the contact surface and pressures between the sole and the floor where braking, support and propulsion phases occurs, allowing the generation of average pressure maps from several individual measurements.
Thus, it can be very useful for the design and evaluation of soles geometries in order to improve anti-slip properties of safety shoes and traction performance of sports footwear.

\section{Disclosure statement}

No potential conflict of interest was reported by the authors.

\section{Funding}

This project has the Eurostars Programme's support [grant number E! 7926] - NANOFRICTION.

\section{Reference}

Li, K.W., \& Chen, C.J. (2004). The effect of shoe soling tread groove width on the coefficient of friction with different sole materials, floors, and contaminants. Applied Ergonomics, 35 (6), 499-507.

\title{
Assessing the effectiveness of micro-spring technology to reduce initial and peak loading rates when integrated into running footwear
}

\author{
Melissa Sutcliffe* and James Richards \\ University of Central Lancashire, Preston, United Kingdom
}

(Received 5 February 2015; accepted 25 March 2015)

\section{Introduction}

Running has long been one of the world's most popular recreational activities. The current total of European runners exceeds 80 million, approximately, $36 \%$ of $15-65$ year-old European population. Running is one of the most widespread activities during which overuse injuries of the lower extremity occur (Hreljac, 2004). It has been estimated that up to $70 \%$ of runners will sustain an overuse injury during any one year period (Caspersen et al., 1984). Previous work has shown that impact forces and high loading rates are linked to injury rates in runners (Davis, Bowser, \& Mullineaux, 2010). Despite the apparent advances in footwear technology and the plethora footwear choices available, we are yet to see a reduction in injury rates amongst runners.

\section{Purpose of the study}

The purpose of this study was to investigate whether a running shoe integrating micro-spring technology showed lower vertical loading rates than a popular bestselling running shoe when tested on a simple drop rig.

\section{Methods}

The drop rig consisted of a variable height and mass, and incorporated a multiflex prosthetic foot (Blatchfords, UK), which could be adjusted to simulate forefoot, rearfoot or flatfoot impacts. Force analysis was conducted using an AMTI BP400600 force platform sampling at $10,000 \mathrm{~Hz}$. It was found that with a mass of $40 \mathrm{~kg}$, a drop height of $10 \mathrm{~mm}$, a peak force of $2000 \mathrm{~N}$ and a loading rate of 80 bodyweight/s could be achieved with a standard shoe. This mapped to the drop height of the foot in terminal swing phase to ground contact and the normal physiologic forces and loading rates experienced in human running testing using the same standard shoe (Richards, Lindley, Sutcliffe, \& Selfe, 2013). The data from each shoe was remarkably consistent, which allowed subtle but important differences between the shoes to be identified during both rearfoot and forefoot impacts. Both the running shoe integrating micro-spring technology and the popular bestselling running shoe were dropped 30 times each on both the forefoot and the rearfoot. Peak vertical loading rate and initial vertical loading rate parameters were then explored.

\footnotetext{
*Corresponding author. Email: msutcliffe1@uclan.ac.uk
}

http://dx.doi.org/10.1080/19424280.2015.1038614 


\section{Results}

The running shoe integrating micro-spring technology showed a $44 \%$ reduction in forefoot initial vertical loading rate and a $30 \%$ reduction in rearfoot initial vertical loading rate as compared to the popular running shoe. The running shoe integrating micro-spring technology showed a $27 \%$ reduction in forefoot peak vertical loading rate and a $7 \%$ reduction in rearfoot peak vertical loading rate as compared to the popular running shoe.

\section{Discussion and Conclusion}

Repeatable testing is essential to determine the effects of different designs and materials which cannot always be achieved with human testing. However, it is vital that such test rigs match as closely as possible the drop heights, peak forces and loading rates experienced with different running styles. The addition of micro-spring technology and also spring damper arrangements in shoes is worthy of further investigation to protect the foot and lower limb against impacts during running and other sporting activities. Differences between forefoot and rear- foot results indicate that the interaction between EVA and springs is critical for maximum spring damper performance. The next stage of this research will involve exploring the effectiveness of micro-spring technology in reducing pain amongst runners with knee pain.

\section{Disclosure statement}

No potential conflict of interest was reported by the authors.

\section{References}

Caspersen, C.J., Powell, K.E., Koplan, J.P., Shirley, R.W., Campbell, C., Sikes, R.K. (1984). The incidence of injuries and hazards in recreational and fitness runners. Medicine and Science in Sport and Exercise, 16, 113-114.

Davis, I.S., Bowser, B., \& Mullineaux, D. (2010). Do impacts cause running injuries? A prospective investigation. Annual Meeting of the American Society of Biomechanics.

Hreljac, A. (2004). Impact and overuse injuries in runners. Medicine and Science in Sport and Exercise, 36(5), 845-849.

Richards, J., Lindley, S., Sutcliffe, M., Selfe, J. (2013). The use of springs in sports footwear, the next big thing or reinventing the wheel? Estuarine, Coastal and Shelf Science.

\title{
Development of a method allowing the correlation of a finite element foot model to human perception of cushioning in footwear
}

\author{
Lise Sissler $^{\mathrm{a} *}$, David Sablon ${ }^{\mathrm{a}}$, André Jacques ${ }^{\mathrm{b}}$, Guillaume Rao ${ }^{\mathrm{b}}$ and Nils Guéguen ${ }^{\mathrm{a}}$ \\ ${ }^{a}$ Decathlon, Villeneuve d'Ascq, France; ${ }^{b}$ Aix-Marseille University, Marseille, France
}

(Received 5 February 2015; accepted 25 March 2015)

\section{Introduction}

The finite element (FE) method is used in a lot of different fields (car, aerospace, building or sports industries) with always the same goal: predicting the response of a structure when subjected to various types of loads. When simulations include FE models of human body parts such as found in the medical or sports fields, the accuracy of the predictions is clearly challenged by the variability associated with human nature. More precisely, everybody is different and experience different sensations when performing a similar task. Linking quantitative data obtained from FE models to subjective data obtained from human subjects, therefore, becomes a real challenge. In the literature, a few studies linking pressure data from FE models and human perception of comfort can be found (Davia et al., 2013; Grujicic et al., 2009; Harih \& Dolsak, 2014). However, most of these studies are limited to static conditions, and none of them focused on the perception of cushioning in footwear.

\section{Purpose of the study}

The purpose of this study was to develop a method allowing for a correlation to be made between the data obtained from an updated version of the FE foot model previously developed by Rao et al. (2011) and cushioning perception data obtained from experimental work with human subjects.

\section{Methods}

Ten subjects were trained to form a panel of experts capable of differentiating the cushioning properties of six different ethylene-vinyl acetate (EVA) materials. The task of the subjects consisted in running barefoot on material

*Corresponding author. Email: lise.sissler@decathlon.com

http://dx.doi.org/10.1080/19424280.2015.1038615 